\title{
Antibacterial Efficacy of Selected Enterococcus Strains Isolated from Traditional Rice Beverage "Handia"
}

\author{
Sujogya Kumar Panda ${ }^{1}$, Laxmipriya Padhi ${ }^{1}$, Akshaya Kumar Bastia ${ }^{2, *}$ \\ ${ }^{1}$ Department of Zoology; North Orissa University; Baripada, India-757003 \\ ${ }^{2}$ Department of Botany; North Orissa University; Baripada, India-757003 \\ *Corresponding Author: bastianou@gmail.com
}

Copyright (C 2013 Horizon Research Publishing All rights reserved.

\begin{abstract}
The present study was conducted to evaluate the antibacterial efficacy of four bacteriocin producing Enterococcus strains isolated from traditional rice beverage, sourced from different sites of Baripada, Odisha, India. The strains were tested against three Gram-positive bacteria viz. Bacillus subtilis, Staphylococcus aureus, S. epidermidis and four Gram-negative bacteria viz. Escherichia coli, Pseudomonas aeruginosa, Salmonella typhimurium, Vibrio cholerae by agar cup method. Surprisingly, it was noticed that most of the Gram-positive bacteria were inhibited by cell free supernatant of isolated strains. The results indicated that the tested Gram-positive bacteria found more sensitive than Gram-negative, and were inhibited. Upon verification, all the isolated strains are found Gram-positive coccus, have the ability to resist the physiological concentration of bile salt, grow at temperature 10 to $42^{\circ} \mathrm{C}$ with $\mathrm{pH}$ range $\geq 9.5$ and tolerate $8.0 \% \mathrm{NaCl}$. Further studies necessary to characterize and purify the bacteriocin produced from the strains.
\end{abstract}

Keywords Enterococcus, Enterocin, Bacteriocin, Lactic Acid Bacteria, Rice Beer, Fermented Food, Enteric Pathogens, Traditional Knowledge

\section{Introduction}

Bacteriocins are ribosomally synthesized peptides that exert their antimicrobial activity against either strains of the same species as the bacteriocin producer (narrow range), or even to more distantly related species (broad range) [1]. Bacteriocins have wide antibacterial spectrum with potential applications in agriculture, food and pharmaceutical industry. It has been noted that a pronounced number of lactic acid bacterial strains of different species and Archaea may produce bacteriocins [1,2]. Although many bacteria can produce bacteriocins, but the potential applications of bacteriocins from lactic acid bacteria have received escalating attention in food and health care, since these bacteria are GRAS (generally regarded as safe) status $[3,4]$. Almost, all LAB based bacteriocins exert their activity at nanomolar concentrations and against a number of bacterial pathogens [2,5]. Even multidrug-resistant nosocomial pathogens such as methicillin-resistant Staphylococcus aureus (MRSA) and vancomycin-resistant enterococci (VRE) may be inhibited [6,7].

Among LAB, the members of the genus Enterococcus are found in many food products with common occurrences in traditional food. Enterococci have the ability to produce bacteriocins, the so-called enterocins, used as probiotics [8]. Enterocin belongs to class IIa bacteriocin composed of small thermostable peptides ( $<10 \mathrm{KDa})$. According to Cintas et al. [9] enterocin have selective antimicrobial activity. The past few years have seen the emergence of class IIa bacteriocins as one of the most interesting groups of antimicrobial peptides for use in food preservation and medicine, as antibiotic complements in treating infectious diseases or antiviral agents [10], or therapeutic agents [11].

Handia, is an inseparable fermented food item in the life of tribals of Mayurbhanj and most other districts of the state of Odisha. The word Handia finds its origin from the word Handi in Odia (local language), means large earthen pot. Handia occupies a key position in the social, cultural and economic life of tribes and accepted as a traditional drink. It is prepared from rice along with some of the locally available plant parts through some indigenous method. Otherwise known as country liquor or "poor man's whiskey", it is relished by one and all and in most occasions.

On the assumption that a specific bacteriocin will have its own unique properties and usefulness in targeting microbial pathogens, this study was aimed to screen the bacteriocin-producing enterococci from Handia against a battery of pathogenic bacteria.

\section{Materials and Methods}

\subsection{Isolation and Enumeration of $\mathbf{L A B}$}

Handia samples in duplicate were collected during the study period in clean, sterilized one liter capacity glass bottles from Baripada, Odisha, India. Enumeration of 
microbial flora like lactic acid bacteria (LAB) was carried out using MRS agar (Man, Rogosa and Sharpe Agar, $\mathrm{pH}=6.4$; Himedia, India) supplemented with Nalidixic acid (20 $\mu \mathrm{g} / \mathrm{ml})$. One $\mathrm{ml}$ of each sample was homogenized with $9 \mathrm{ml}$ of sterile water. The homogenate was serially diluted to $10^{-6}$ dilution and $100 \mu \mathrm{l}$ aliquots of the appropriate dilutions directly inoculated into petriplate containing reference isolation media. The petri-plates were incubated at $35^{\circ} \mathrm{C}$ for 48 hours to calculate the population of bacteria by using colony counter (Table-1; Figure-1). The purity of the organisms was checked by streaking them in the same media, followed by microscopic examination. Pure cultures were maintained in agar slants at $4^{\circ} \mathrm{C}$ and glycerol at $-20{ }^{\circ} \mathrm{C}$.

Table 1. Enumeration of LAB on MRS agar

\begin{tabular}{|c|c|c|}
\hline $\begin{array}{c}\text { Sampling location near } \\
\text { Baripada }\end{array}$ & $\mathrm{pH}$ & $\begin{array}{c}\text { LAB population }(100 \mu \mathrm{l}) \\
(\text { Mean } \pm \text { SD) }\end{array}$ \\
\hline Palbani & $4.24 \pm 0.03$ & $5833 \pm 472$ \\
\hline Takatpur & $4.46 \pm 0.04$ & $9100 \pm 624$ \\
\hline Tulasichoura & $4.67 \pm 0.03$ & $2133 \pm 57$ \\
\hline
\end{tabular}
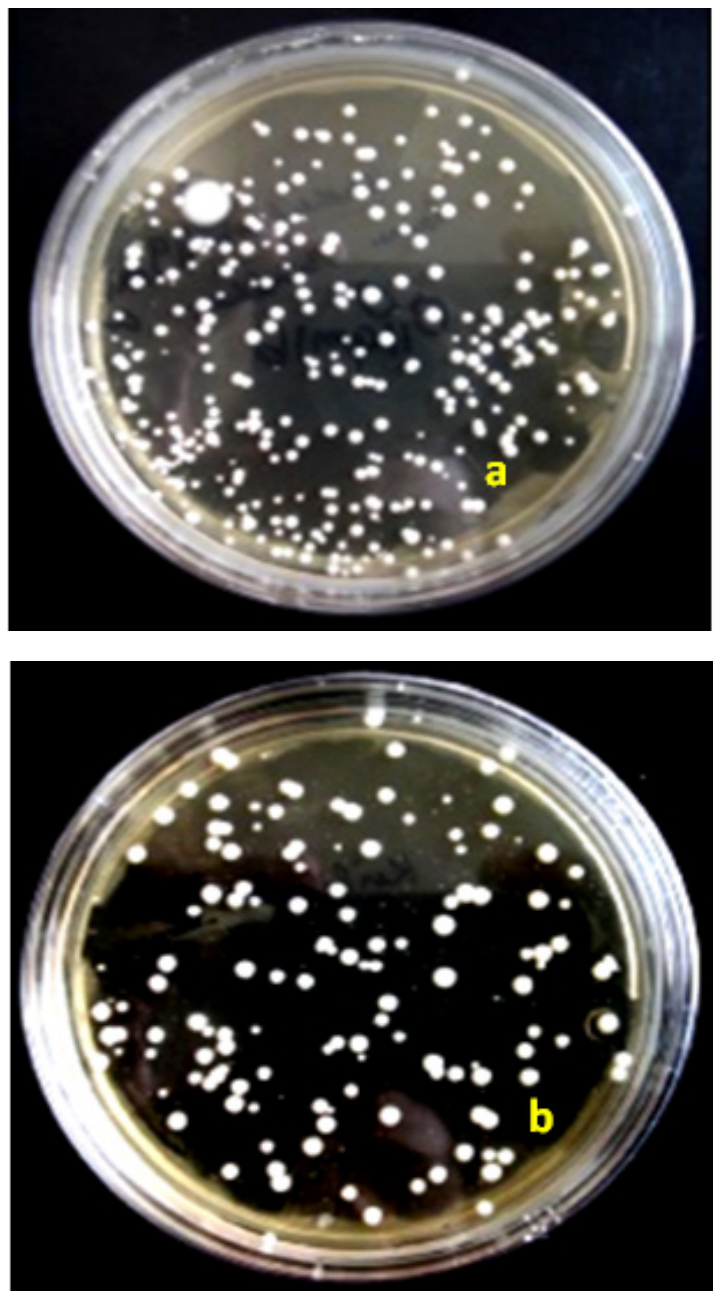

Figure $1(\mathbf{a} \& \mathbf{b})$. Colonies of LAB on MRS agar collected form two different localities (a. Palbani; b. Tulsichoura)

\subsection{Isolation and Identification of Enterococcus}

The following tests were carried out for presumptive identification of the isolates; observation of colony characteristics and cell morphology, Gram staining, catalase and oxidase production, growth at $10{ }^{\circ} \mathrm{C}-42 \mathrm{C}$, growth in the presence of $\mathrm{NaCl}(5,8 \mathrm{~g} / 100 \mathrm{ml})$ and at $\mathrm{pH} 9.5$, as well as esculin hydrolysis on bile-esculin agar (BEA) [12]. Those colonies belonging to the Enterococcus genus were identified to species level by means of sugar fermentation according to the Manero and Blanch scheme [13].

\subsection{Screening for Antimicrobial Activity}

\subsubsection{Bacterial Strains and Growth Conditions}

The bacterial strains used as indicator microorganisms as well as conditions for growth are listed in Table 2. The bacterial cultures were maintained on MRS agar slants and stored at $4{ }^{\circ} \mathrm{C}$. Activation of the bacterial strain was carried out by streaking culture from the slants on to a Muller Hinton agar (MHA) plate and incubating overnight at $37{ }^{\circ} \mathrm{C}$. Single colony was picked up from each plate and transferred to nutrient broth, incubated for 1 day at $37{ }^{\circ} \mathrm{C}$ prior to the test. Antibiogram was done by disc diffusion method [14] with commonly used antibiotics. Antibiotic sensitivity was tested in MHA plates. The test microbes were removed from the slant aseptically with inoculating loops and transferred to separate test tubes containing $5.0 \mathrm{ml}$ of sterile distilled water. Inoculum was added until the turbidity equaled 0.5 McFarland $\left(10^{8} \mathrm{CFU} / \mathrm{ml}\right)$. For each of the bacteria, one milliliter of the test tube suspension was added to $15-20 \mathrm{ml}$ of nutrient agar and transferred to the agar plate $(90 \mathrm{~mm}$ diameter). After cooling the inoculated agars at room temperature for $25 \mathrm{~min}$, antibiotic sensitivity test discs were placed on the surface of solid agar. The plates were incubated at $37^{\circ} \mathrm{C}$ and zone of inhibition formed around the discs were measured (in $\mathrm{mm}$ ) (Table-2). The multiple antibiotic resistance index was determined by using the formula,

$\mathrm{MAR} \%=\frac{\text { Number of antibiotics to which the organism shared resistance }}{\text { Number of antibiotics tested }} \times 100$.

\subsubsection{Detection of Inhibitory Activity}

Cell-free culture supernatants (CFSs) obtained by centrifugation of overnight cultures at 8000 RPM, maintained at $4{ }^{\circ} \mathrm{C}$ for $10 \mathrm{~min}$ were adjusted to $\mathrm{pH} 7.0$ with $0.5 \mathrm{~mol} / \mathrm{l} \mathrm{NaOH}$ and heated at $100{ }^{\circ} \mathrm{C}$ for $5 \mathrm{~min}$ in order to inactivate endogenous proteases. Afterwards, CFS was filtered using $0.22 \mu \mathrm{m}$ pore size cellulose filter (Millipore) and stored at $-20{ }^{\circ} \mathrm{C}$ for further use. The antimicrobial activity of the CFS was determined by the agar well diffusion assay (AWDA) [15]. The supernatant $(40 \mu \mathrm{l})$ was placed in wells (6 mm in diameter) cut in MHA plates $(20 \mathrm{ml})$ seeded with a stationary phase cell suspension of the each pathogenic bacteria listed in Table 1 . The plates were incubated at $37^{\circ} \mathrm{C}$ for $24 \mathrm{~h}$. 
Table 2. Antibacterial resistance and MAR index of all tested bacteria

\begin{tabular}{|c|c|c|c|c|}
\hline \multirow{2}{*}{ Name of the organism } & \multicolumn{2}{|c|}{ Relevant properties } & \multirow{2}{*}{ MAR \% } & \multirow{2}{*}{ Sources } \\
\hline & Resistant to & Sensitive to & & \\
\hline Escherichia coli & Ak, Ap, B, Ctn, E, Aug, Ce, Nal & A, C, Ch, Caz, G, Gf, Lvx, Ofl, Pb, St, Te, & 40 & $\begin{array}{l}\text { MTCC 1098, } \\
\text { Chandigarh }\end{array}$ \\
\hline Pseudomonas aeruginosa & $\begin{array}{c}\text { A, Ak, Ap, B, Ctn, E, Aug, Ce, } \\
\text { Nal, } \mathrm{Pb}\end{array}$ & C, Ch, Caz, G, Gf, Lvx, Ofl, St, Te, Vn & 50 & $\begin{array}{l}\text { MTCC 1034, } \\
\text { Chandigarh }\end{array}$ \\
\hline Salmonella typhimurium & $\begin{array}{c}\text { Ak, Ap, B, Ctn, E, Aug, Ce, } \\
\text { Nal, Pb }\end{array}$ & A, C, Ch, Caz, G, Gf, Lvx, Ofl, St, Te, Vn & 45 & $\begin{array}{l}\text { MTCC 3216, } \\
\text { Chandigarh }\end{array}$ \\
\hline Vibrio cholerae & $\begin{array}{c}\text { A, Ak, Ap, Aug, B, E, Gt, G, } \\
\text { St, Vn }\end{array}$ & C, Ce, Cez, Ctn, $\underset{\text { Lvx }}{\mathrm{Ch}, \mathrm{Nal}, \mathrm{Olf}, \mathrm{Pb}, \mathrm{Te},}$ & 50 & $\begin{array}{l}\text { MTCC 3904, } \\
\text { Chandigarh }\end{array}$ \\
\hline Bacillus subtilis & $\mathrm{Ak}, \mathrm{Ap}, \mathrm{B}, \mathrm{Ctn}, \mathrm{Ce}, \mathrm{Nal}$ & $\begin{array}{c}\text { A, Aug, C, Cez, Ch, Olf, Pb, Te, Lvx, } \\
\text { E, Gt, G, St, Vn }\end{array}$ & 40 & $\begin{array}{l}\text { MTCC 7164, } \\
\text { Chandigarh }\end{array}$ \\
\hline Staphylococcus aureus & $\begin{array}{c}\text { Ak, Ap, B, Aug, Ctn, G, Ce, } \\
\text { Nal, } \mathrm{Pb}\end{array}$ & A, C, Cez, Ch, Olf, Te, Lvx, E, Gt, St, Vn & 45 & $\begin{array}{l}\text { MTCC 1144, } \\
\text { Chandigarh }\end{array}$ \\
\hline Staphylococcus epidermidis & $\mathrm{Ak}, \mathrm{Ap}, \mathrm{B}, \mathrm{Ce}, \mathrm{Nal}$ & $\begin{array}{c}\text { A, C, Aug, Ctn, Cez, Ch, E, Gt, G, Olf, } \\
\text { Te, Lvx, Pb St,Vn }\end{array}$ & 25 & $\begin{array}{l}\text { MTCC 3615, } \\
\text { Chandigarh }\end{array}$ \\
\hline
\end{tabular}

\subsection{Analysis of Extracellular Enzymes}

Extracellular enzymes such as amylase, gelatinase, lipase and protease were analyzed through plate test by growing individual bacterial isolates in Starch agar (amylase), Gelatin agar (gelatinase), Peptone agar (lipase) and Skim milk agar (protease). After four days of incubation at $35^{\circ} \mathrm{C}$, culture plates were tested for enzyme activity by adding iodine solution in amylase plates, $\mathrm{HgCl}_{2}\left(15 \% \mathrm{HgCl}_{2}\right.$ in $20 \% \mathrm{HCl}$ ) for gelatinase in respective plates. The clear zone formation around the growing colony was considered as positive. The lipase activity of bacterial isolates was determined on lipase test medium and the formation of opaque whitish zone around the growing colony was considered as positive. The formation clear of zone of inhibition in skim milk agar was considered as positive for protease activity.

\subsection{Screening of Haemolytic Activity}

Production of haemolysis was determined by streaking the Enterococcus strain (grown in MRS broth for $18 \mathrm{~h}$ ) in Blood agar plates supplemented with $50 \mathrm{ml}$ human blood. After incubation at $37^{\circ} \mathrm{C}$ for $24 \mathrm{~h}$ under aerobic conditions, plates were examined for haemolysis. Presence of clear zone around the colonies was interpreted as $\beta$-haemolysis

\section{Results}

Fourteen Enterococcus strains isolated from Handia were assayed for their antibacterial activity with potent bacteriocin against three Gram-positive bacteria (B. subtilis, $S$. aureus, $S$. epidermidis) and four gram-negative bacteria (E. coli, P. aeruginosa, S. typhimurium, V. cholerae) by AWDA. Four strains viz. 38M1B, 68M1, 129M1B and 144M1 exhibited inhibitory activity against at least two test bacterial species. Subsequently, these strains were subjected to further study such as growth at different temperature, $\mathrm{pH}$, salt tolerance, bile tolerance and enzymatic activity such as amylase, gelatinase and protease.

The tests commonly used to assign Gram-positive groups in form of coccus and as member of genus Enterococcus are listed in Table-3,4,5. All these strains were identified as the members of the genus Enterococcus based on the following test viz. absence of catalase and oxidase, Gram-positive coccus (Figure-2) with ability to grow at temperature $10-42{ }^{\circ} \mathrm{C}, \mathrm{pH} \geq 9.5$ and tolerate $8.0 \% \mathrm{NaCl}$. Further identification to species level was based on carbohydrate fermentation. The genus is charecterised by production of acid from sugars such as manitol, sorbitol, lactose, sucrose, xylose, rhamanose and esculin. Arginine dehydrolysis test resulted that all these strains have capability to deaminate arginine. The strains show negative for indole test while positive for methyl red, Voges-Praskuer and citrate test (Table-4). The isolates were distinguished based on biochemical and sugar fermentation test, identified as Enterococcus faecium (arabinose+ve, glycerol-ve) and $E$. faecalis (arabinose-ve, glycerol+ve) (Table-5). None of the test strains demonstrate haemolytic activity when grown in human blood agar. Also the strains do not have the ability to produce extracellular enzyme such as protease, amylase and lipase. 


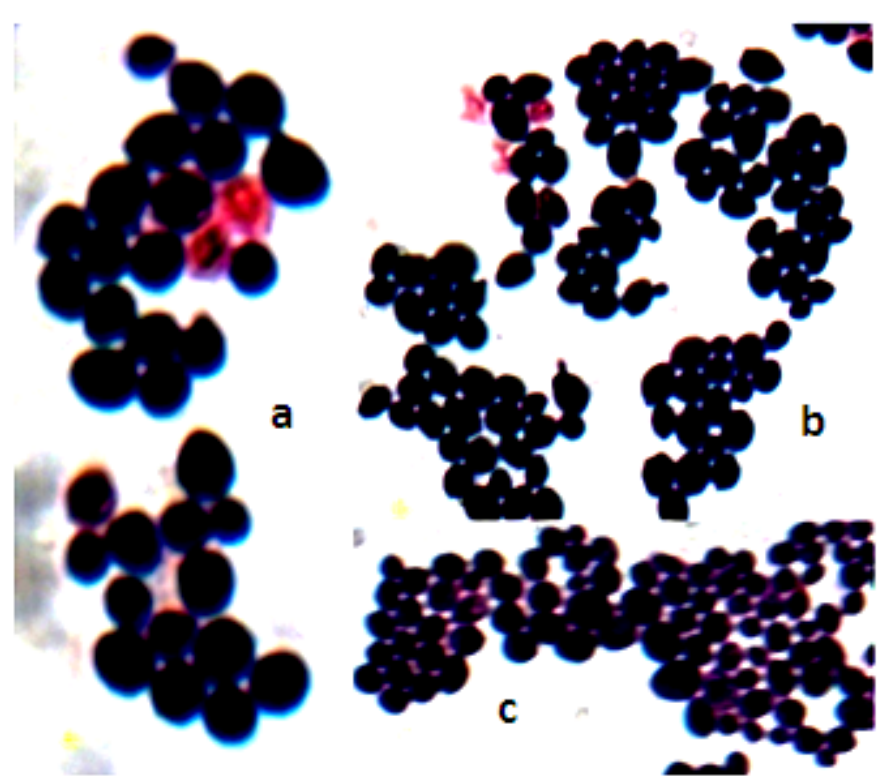

Figure 2 (a. b \& c). Different forms of Enterococcus shown by Gram stain

Table 3. Growth characteristics of selected Enterococcus species

\begin{tabular}{|c|c|c|c|c|}
\hline \multirow{2}{*}{ Characteristic of the organism } & \multicolumn{4}{|c|}{ Gram-positive Cocci } \\
\cline { 2 - 5 } & $144 \mathrm{M} 1$ & $129 \mathrm{M} 1$ & $68 \mathrm{M} 1$ & $38 \mathrm{M} 1 \mathrm{~B}$ \\
\hline Chain formation & - & + & - & - \\
\hline Gas from glucose & - & \pm & - & - \\
\hline Growth at $10{ }^{\circ} \mathrm{C}$ & + & \pm & - & + \\
\hline Growth at $42{ }^{\circ} \mathrm{C}$ & + & + & +++ & + \\
\hline Growth in $5 \% \mathrm{NaCl}$ & +++ & +++ & +++ & +++ \\
\hline Growth in $8 \% \mathrm{NaCl}$ & ++ & ++ & ++ & ++ \\
\hline Growth at $\mathrm{pH} 4.5$ & ++ & ++ & ++ & ++ \\
\hline Growth at $\mathrm{pH} 9.5$ & ++ & ++ & & ++ \\
\hline
\end{tabular}

Table 4. Results of biochemical test of selected Enterococcus species

\begin{tabular}{|c|c|c|c|c|}
\hline \multirow{2}{*}{ Name of the test } & \multicolumn{4}{|c|}{ Strain designation } \\
\cline { 2 - 5 } & $144 \mathrm{M} 1$ & $129 \mathrm{M} 1$ & $68 \mathrm{M} 1$ & $38 \mathrm{M} 1 \mathrm{~B}$ \\
\hline Catalase & - & - & - & - \\
\hline Oxidase & - & - & - & - \\
\hline Motility & - & - & - & - \\
\hline Indole & - & - & + & + \\
\hline Methyl Red & + & + & + & + \\
\hline VogesPrauskuer & + & + & + & + \\
\hline Citrase & + & + & + & + \\
\hline Arginine & + & + & - & + \\
\hline Bile esculin & + & + & - & - \\
\hline Amylase & - & + & - & - \\
\hline Protease & - & - & - & - \\
\hline Gelatinase & - & - & - & - \\
\hline Lipase & - & - & - \\
\hline Haemolytic & & & + & + \\
\hline
\end{tabular}


\pm , response varies when repeated

Table 5. Results of sugar fermentation

\begin{tabular}{|c|c|c|c|c|c|c|c|c|c|c|c|c|c|c|c|}
\hline \multirow{2}{*}{$\begin{array}{c}\text { Strain } \\
\text { Designation }\end{array}$} & \multirow{2}{*}{ Identification } & \multicolumn{14}{|c|}{ Sugar utilization } \\
\hline & & 1 & 2 & 3 & 4 & 5 & 6 & 7 & 8 & 9 & 10 & 11 & 12 & 13 & 14 \\
\hline $38 \mathrm{M} 1 \mathrm{~B}$ & E. faecalis & - & + & - & + & - & - & + & + & - & - & + & + & + & + \\
\hline $68 \mathrm{M} 1$ & E. faecium & \pm & + & \pm & - & - & - & + & + & - & - & + & + & + & + \\
\hline 129M1B & E. faecalis & - & + & - & + & - & - & + & + & - & - & + & + & + & + \\
\hline $144 \mathrm{M} 1$ & E. faecalis & - & + & - & + & - & - & + & + & - & - & + & + & + & + \\
\hline
\end{tabular}

"+”= Acid production; "-“"= No production of acid; 1-Arabinose; 2-Esculin; 3-Glucose; 4-Glyceral; 5-Glycine; 6-Inulin; 7-Lactose; 8-Mannitol; 9-Mannose; 10-Raffinose; 11-Rhamnose; 12-Sorbitol; 13-Sucrose; 14-Xylose; Sugar concentration $(0.5 \%)$

Table 6. Screening of bacteriocin produced Enterococcus isolated from Handia

\begin{tabular}{|c|c|c|c|c|c|c|c|}
\hline \multirow{2}{*}{$\begin{array}{c}\text { Strain } \\
\text { Designation }\end{array}$} & \multicolumn{3}{|c|}{ Bacterial strain } \\
\cline { 2 - 8 } & Ec & Pa & St & Vc & Bs & Sa & Se \\
\cline { 2 - 8 } & - & - & - & - & + & ++ & + \\
\hline $38 \mathrm{M} 1 \mathrm{~B}$ & - & + & - & - & - & + \\
\hline $68 \mathrm{M} 1$ & - & - & - & - & - & ++ & + \\
\hline $129 \mathrm{M} 1 \mathrm{~B}$ & - & - & - & - & - & + \\
\hline
\end{tabular}

(-) No inhibition, $(+)$ Zone of inhibition $\leq 10 \mathrm{~mm},(++)$ Zone of inhibition $\leq 15 \mathrm{~mm}$; All zone of inhibition including $6 \mathrm{~mm}$ cork borer; Ec-Escherichia coli; Pa-Pseudomonas aeruginosa; St-Salmonella typhimurium; Vc-Vibrio cholerae; Bs-Bacillus subtilis; Sa-Staphylococcus aureus; Se-Staphylococcus epidermidis

\section{Discussion}

The genus Enterococcus is the most controversial group of lactic acid bacteria [16]. On one hand, enterococci have been used in many different applications as starters or adjunct cultures, and they are well known for their major role in improving flavour development and quality of food products [17]. On the other hand, the role of enterococci in disease has raised questions on their safety for use in foods or as probiotics since they are important nosocomial pathogens that cause bacteraemia, endocarditis and other infections $[18,19]$. They also play beneficial roles in foods and have relatively low virulence. The $\beta$-haemolysin/bacteriocin is a conformed enterococcal virulence factor. This is a cellular toxin that enhances virulence in animal models [20]. However, none of the test strains display haemolytic activity when grown in human blood agar.

Proteases are also believed to be involved in enterococcal pathology. Gelatinase is an extracellular metalloendopeptidase that acts on collagenous material in tissues. Production of gelatinase increased pathogenicity in an animal model [21]. Our results showed no degradative activity of the enzyme on any of the strains tested following gelatinase agar.

In the present study four isolates of Enterococci from traditional rice beverage Handia was isolated and displayed antagonistic properties. The most active strain (129M1) was identified as E. faecalis. These results are in agreement with the earlier reports with narrow spectrum action due to presence of enterocin [22]. Though, the bacterial strains did not have any enzymatic activity such as gelatinase and protease, the activity may be due to the formation of bacteriocin like inhibitory substances.

The result indicated that the test Gram-positive bacteria are highly sensitive in compared to Gram-negatives. The absence of inhibitory activity against Gram-negative bacteria is not surprising as most of $\mathrm{LAB}$ bacteriocin inhibit the growth of closely related Gram-positive bacteria. Authors supposed that this may be due to composition of the cell wall among Gram-positive and Gram-negative bacteria. It may be recalled that penicillin and some of other prominent antibiotics are also selective in their inhibitory action; most of them inhibit Gram-positive bacteria. Gram-negative bacteria have an outer phospholipid membrane carrying the structural lipopolysaccharide components. This makes the cell wall impermeable to antimicrobial substances. The Gram-positive bacteria on the other hand are more susceptible, having only an outer peptidoglycan layer which is not an effective permeability barrier. Therefore, the cell walls of Gram-negative organisms are more complex in lay out than the Gram-positive ones, acting as diffusion barrier and making them less susceptible to the antimicrobial agents 
than that of Gram-positive bacteria. Enterococci, plays the major part of the human gastrointestinal micro flora [23], are widespread in various food especially associated with fermented foods [24]. Generally, the presence of Enterococci in food products is considered as a sign of fecal contamination, but more recently they became accepted as part of the normal flora and are commonly used as probiotics [25].

\section{Conclusion}

The bacteriocin produced by the Enterococcus strains from Handia showed antibacterial activity. These strains lack enzymatic activity (protease, haemolytic and gelatinase), that signifies the activity is due to the formation of bacteriocin like inhibitory substances. Further research is necessary to purify the bacteriocin and study their detail character; as a result it can be widely applied in food and pharmaceutical industry.

\section{Acknowledgements}

The present research has been funded by the Department of Science and Technology, Government of Odisha (Grant No. ST-BIO-70/2010/ST). We are grateful to the authorities of North Orissa University for providing necessary facilities to carry out this research.

\section{REFERENCES}

[1] Y Belguesmia, K Naghmouchi, N Chihib. Class IIa bacteriocins: current knowledge and perspectives. In D. Drider, \& S. Rebuffat (Eds.), Prokaryotic antimicrobial peptides, New York: Springer Publishing Company, 171-195, 2011.

[2] OB Chahad, M El Bour, P Calo-Mata, A Boudabous, J Barros-Velàzquez. Discovery of novel biopreservation agents with inhibitory effects on growth of food-borne pathogens and their application to seafood products. Research in Microbiology, Vol. 163, No. 1, 44-54, 2012.

[3] S Anastasiadou, M Papagianni, G Filiousis, L Ambrosiadis, P Koidis. Growth and metabolism of a meat isolated strain of Pediococcus pentosaceus in submerged fermentation. Purification, characterization and properties of the produced pediocin SM-1. Enzyme and Microbial Technology, Vol. 43, 448-454, 2008.

[4] M Papagianni, S Anastasiadou. Pediocins: The bacteriocins of Pediococci. Sources, production, properties and applications. Microbial Cell Factories, Vol. 8, No. 3, 1-16, 2009.

[5] K Indira, S Jayalakshmi, A Gopalakrishnan, M Srinivasan. Biopreservative potential of marine Lactobacillus spp. African Journal of Biotechnology, Vol. 5, 2287-2296, 2011.
[6] B Karska-Wysocki, M Bazo, W Smoragiewicz. Antibacterial activity of Lactobacillus acidophilus and Lactobacillus casei against methicillin-resistant Staphylococcus aureus (MRSA). Microbiological Research, Vol. 165, No. 8, 674-686, 2010.

[7] N Mojgani, C Amirinia. Kinetics of growth and bacteriocin production in L. casei RN 78 isolated from a dairy sample in IR Iran. International Journal of Dairy Science, Vol. 2, 1-12, 2007.

[8] FP Rivas, MP Castro, M Vallejo, E Marguet, CA Campus. Antibacterial potential of Enterococcus faecium strains isolated from ewes' milk and cheese. LWT - Food Science and Technology, Vol. 46, 428-436, 2012.

[9] LM Cintas, P Casaus, LS Havarstein, PE Hernandez, LF Nes. Biochemical and genetic characterization of enterocin $\mathrm{P}$, a novel sec-dependent bacteriocin from Enterococcus faecium P13 with a broad antimicrobial spectrum. Applied and Environmental Microbiology, Vol. 63, 4321-4330, 1997.

[10] D Drider, G Fimland, Y Héchard, LM McMullen, H Prévost. The continuing story of class IIa bacteriocins. Microbiology and Molecular Biology Reviews, Vol. 70, No. 2, 564-582, 2006.

[11] J Jasniewski, C Cailliez-Grimal, E Gelhaye, AM Revol-Junelles. Optimization of the production and purification processes of carnobacteriocins Cbn BM1 and Cbn B2 from Carnobacterium maltaromaticum CP5 by heterologous expression in Escherichia coli. Journal of Microbiological Methods, Vol. 73, No. 1, 41-48, 2008.

[12] K Schleifer, R Kilpper-Bälz. Transfer of Streptococcus faecalis and Streptococcus faecium to the genus Enterococcus nom. rev. as Enterococcus faecalis comb. nov. and Enterococcus faecium comb. nov sp. International Journal of Systematic Bacteriology, Vol. 34, 31-34, 1984.

[13] A Manero, AR Blanch. Identification of Enterococcus spp. with a biochemical key. Applied and Environmental Microbiology, Vol. 65, 4425-4430, 1999.

[14] AW Bauer, WMM Kirby, JC Sherris, M Turck. Antibiotic susceptibility testing by a standardized single disk method. American Journal of Clinical Pathology, Vol. 45, 493-496, 1966.

[15] U Schillinger, FK Lücke. Identification of Lactobacilli from meat and meat products. Food Microbiology, Vol. 4, 199-208, 1987.

[16] MR Foulquié Moreno, P Sarantinopoulos, E Tsakalidou, L De Vuyst. The role and application of enterococci in food and health. International Journal of Food Microbiology, Vol. 106, $1-24,2006$

[17] M Hugas, M Garriga, MT Aymerich. Functionality of enterococci in meat products. International Journal of Food Microbiology, Vol. 88, 223-233, 2003.

[18] G Giraffa. Enterococci from foods. FEMS Microbiology Reviews, Vol. 26, 163-171, 2002.

[19] N Ben Omar, A Castro, R Lucas, H Abriouel, NMK Yousif, CMAP Franz, et al. Functional and safety aspects of enterococci isolated from different Spanish foods. Systematic and Applied Microbiology, Vol. 27, 118-130, 2004.

[20] MS Gilmore, RA Segarra, MC Booth, CP Bogie, LR Hall, DB Clewell. Genetic structure of the Enterococcus faecalis 
plasmid pAD1-encoded cytolytic toxin system and its relationship to 1 antibiotic determinants. Journal of Bacteriology, Vol. 176, 7335-7344, 1994.

[21] KV Singh, TM Coque, GM Weinstock, BE Murray. In vivo testing of an Enterococcus faecalis efaA mutant and use of efaA homologs for species identification. FEMS Immunology and Medical Microbiology, Vol. 21, 323-331, 1998.

[22] CM Franz, MJ Van Belkum, WH Holzapfel, H Abriouel, A Gálvez. Diversity of enterococcal bacteriocins and their grouping in a new classification scheme. FEMS Microbiology Reviews, Vol. 31, 293-310, 2007.
[23] MM Huycke, DF Sahm, MS Gilmore. Multiple-drug resistant enterococci: the nature of the problem and an agenda for the future. Emerging Infectious Diseases, Vol. 4, 239-249, 1998.

[24] CM Franz, ME Stiles, KH Schleifer, WH Holzapfel. Enterococci in foods-a conundrum for food safety. International Journal of Food Microbiology, Vol. 88, 105-122, 2003.

[25] A Mercenier, S Pavan, B Pot. Probiotics as biotherapeutic agents: present knowledge and future prospects. Current Pharmaceutical Design, Vol. 9, 175-191, 2003. 